\title{
Intermittent Sprinkler Irrigation for Establishment of Bare Root Strawberry Transplants ${ }^{1}$
}

\author{
E.A. Golden, J.R. Duval, E.E. Albregts, and C.M. Howard ${ }^{2}$
}

Bare rooted strawberry transplants set in black polyethylene mulched beds are established by irrigating continuously for approximately 8 hours daily with overhead sprinklers for 10 to 14 days. Irrigation is provided to reduce the water stress caused by the damaged root system of the transplant, the high surface temperature of the black mulch, the high ambient air temperature, and dry weather condition usually present at time of transplanting. Without irrigation, transplants become defoliated; this results in considerable plant mortality and /or a delay in fruiting. Early yield is economically important in central Florida.

Presently, 4-20 inches of water are required to establish transplants depending on conditions of transplants and weather conditions. Further urbanization of the strawberry production area in Florida is likely to lead to increased regulations on water usage. An intermittent sprinkler irrigation system may provide enough water to meet transplants needs while reducing the overall water output.

In experimentation conducted at the GCREC-Dover, transplants were thoroughly moistened each day before starting irrigation cycles. The irrigation intervals ( $\mathrm{min} \mathrm{on} / \mathrm{min}$ off) tested were:
$3 / 17,5 / 25,5 / 15,10 / 20,15 / 15$, and continuous, which served as the control, the first season, and, 5/25, 5/15, $5 / 10$, and continuous the second season. Normal irrigation was then resumed for the remainder of the season.

The longer the "off interval", the greater the leaves lost by the end of establishment period. Irrigation intervals of $3 / 17$ and 5/25 increased plant mortality. Yield of strawberries were not significantly different for $5 / 15,10 / 20,5 / 10$, and $15 / 15$ intervals and the control. Table 1 shows the effect of treatments on marketable fruit yields, the reduction in water use correlates to the following: $5 / 15=75 \%, 10 / 20$ and $5 / 15=66 \%$, and $15 / 15=$ $50 \%$.

\section{Summary}

In summary, Foliage should not wilt, low humidity and wind speeds greater than $10 \mathrm{mph}$ accelerate leaf drying, and during the heat of the day, foliage should receive irrigation soon after drying from the previous irrigation cycle. Keen observations during the establishment period will determine intermittent irrigation cycles of transplants that can

1. This is document HS947, a publication of the Horticultural Department, Florida Cooperative Extension Service, Institute of Food and Agricultural Sciences, University of Florida. Publication Date: December 2003. Please visit the EDIS Website at http://edis.ifas.ufl.edu.

2. E.A. Golden, biological scientist, J.R. Duval, assistant professor, E.E. Albregts, professor, C.M. Howard, professor, Gulf Coast Research and Education Center, Florida Cooperative Extension Service, Institute of Food adn Agricultural Sciences, University of Florida, Gainesville, FL 32611. 
reduce water usage and fertilizer leaching without affecting early or seasonal fruit yield.

Table 1. Marketable strawberry fruit yield for two seasons.

\begin{tabular}{|c|c|c|c|c|c|c|c|}
\hline \multirow[b]{3}{*}{$\begin{array}{l}\text { Harvest } \\
\text { Period }\end{array}$} & \multicolumn{7}{|c|}{ Treatments } \\
\hline & \multicolumn{7}{|c|}{ Mintues on/off } \\
\hline & $3 / 17$ & $5 / 25$ & $5 / 15$ & $10 / 20$ & $5 / 10$ & $15 / 15$ & Control \\
\hline \multicolumn{4}{|l|}{ Season 1} & \multicolumn{2}{|c|}{ Flats $/ A^{y}$} & & \\
\hline Early & $228 b^{z}$ & $256 b$ & $289 a b$ & \multicolumn{2}{|l|}{$360 a$} & $350 a$ & $378 a$ \\
\hline Seasonal & $2408 a b$ & $2231 b$ & $2578 a$ & \multicolumn{2}{|l|}{$2578 a$} & $2640 a$ & $2533 a$ \\
\hline \multicolumn{4}{|l|}{ Season 2} & \multicolumn{2}{|c|}{ Flats/A } & & \\
\hline \multicolumn{2}{|l|}{ Early } & $273 b$ & $506 a$ & & $469 a$ & & $444 a$ \\
\hline \multicolumn{2}{|l|}{ Seasonal } & $2373 a$ & $2951 a$ & & $2978 a$ & & $2898 a$ \\
\hline \multicolumn{8}{|c|}{$\begin{array}{l}{ }^{z} \text { Means in the same row followed by the same letter are not significantly different. } \\
\text { (Duncan's multiple range test, } P<0.05) \\
{ }^{y} \text { One flat }=10.25 \text { lbs. }\end{array}$} \\
\hline
\end{tabular}

